Check for updates

Cite this: RSC Adv., 2019, 9, 12247

Received 14th November 2018

Accepted 18th March 2019

DOI: $10.1039 / c 8 r a 09395 d$

rsc.li/rsc-advances

\section{The caffeic acid moiety plays an essential role in attenuating lipid accumulation by chlorogenic acid and its analogues $\dagger$}

\begin{abstract}
Xiaoxue Cao, (D) Chongming Wu, $\$$ Yu Tian (D)* and Peng Guo*
Chlorogenic acid (5-caffeoylquinic, CA) possesses distinct hypolipidemic properties in vivo and in vitro, yet the structure-activity relationship (SAR) of CA on lipid metabolism remains unknown. To achieve this aim, we designed and synthesized two sets of CA analogues and evaluated their efficacies to prevent oleic acid (OA)-elicited lipid accumulation in HepG2 cells. Blockage of all hydroxyl and carboxyl groups on the quinic acid moiety did not deteriorate the hypolipidemic effect of CA while blockage of all phenolic hydroxyl groups on the caffeic acid moiety abolished the activity of CA. Further replacement of the quinic acid moiety with cyclohexane and modification of individual phenolic hydroxyl groups on the caffeic acid moiety showed that the phenolic-hydroxyl-reserved analogues displayed a more potent hypolipidemic effect than CA, whereas the analogue with no phenolic hydroxyl displayed little effect on the OA-elicited lipid accumulation. In accordance, the modulating effects of CA on the transcription of the lipogenic gene sterol-regulatory element binding protein (SREBP)1c/1a, acetyl-CoA carboxylase (ACC), fatty acid synthase (FAS) and peroxisome proliferator-activated receptor $\alpha$ (PPAR $\alpha$ ) were also abolished when the phenolic hydroxyl groups on the caffeic acid moiety were blocked. Our results suggest that the phenolic hydroxyl on the caffeic acid moiety is vital for the lipid-lowering activity of CA.
\end{abstract}

\section{Introduction}

Hyperlipidemia, a disorder of lipid metabolism, involves an imbalance of cholesterol level. Other forms include hypertriglyceridemia and mixed hyperlipidemia in which both cholesterol and triglyceride levels are elevated. It is known as a major cause of cardiovascular disease (CVD) that currently contributes to half of the world's mortality. ${ }^{1-3}$ Patients with hyperlipidemia are at approximately twice the risk of developing CVD compared to those with normal total cholesterol level. ${ }^{4}$ In current clinical prescription, statins are the main treatment for hyperlipidemia. However, they are associated with numerous adverse events and limitations., ${ }^{5,6}$ Thus developing novel drugs originating from natural products of appreciable action to combat lipid metabolic disorders would have significant medical and economic impacts.

A general approach to drug discovery, which has been embraced by the pharmaceutical industry, includes developing lead compounds and structure modification of templates. It lies in structure-activity relationship (SAR)-oriented synthesis. ${ }^{7,8}$

Institute of Medicinal Plant Development, Chinese Academy of Medical Sciences, Peking Union Medical College, Beijing 100193, China. E-mail: ytian@implad.ac.cn; pguo@implad.ac.cn; Tel: +86-10-5783-3235

$\dagger$ Electronic supplementary information (ESI) available. See DOI: 10.1039/c8ra09395d

\$ These authors contributed equally to this work.
Formulation of SARs provides information of essential functional groups to guide practical structure optimization of parental compounds, ${ }^{9}$ which further benefits lowering side effects and improving efficacy. Therefore, the study of SARs of lead compounds is considerably vital in drug discovery.

Chlorogenic acid (5-CQA, CA), the ester of caffeic acid with quinic acid (shown in Fig. 1), is distributed in a wide range of plants and human diet, such as Lonicera japonica Thunb, ${ }^{\mathbf{1 0}}$ coffee and tea. ${ }^{\mathbf{1 1}}$ It possesses various biological properties. ${ }^{\mathbf{1 2 - 1 5}}$ Recent studies demonstrated a distinct potency of CA on improving dyslipidemia. ${ }^{16-19}$ Our previous works have indicated CA dramatically attenuated lipid accumulation in vivo and in vitro. ${ }^{20-23}$ Existing studies have reported structure-activity relationships on certain effects of CA. For instance, caffeic acid moiety was important for suppression of hepatic gluconeogenesis and hyperglycemia. ${ }^{24}$ The 3,4-position hydroxyl groups were responsible for its antibacterial activity. ${ }^{25}$ However, the functional groups in structure that are responsible for antihyperlipidemia activity have not been characterized yet.

In this study, in order to investigate the primary structurehypolipidemic activity relationship of chlorogenic acid and clarify the role of the caffeic acid or quinic acid moiety on lipidlowering effect, an implementation was designed as shown in Fig. 2. We first modified the active groups such as the hydroxyl and carboxyl groups on quinic acid moiety in the A ring and the phenolic hydroxyl groups on caffeic acid moiety in the B ring. Moreover, a series of cinnamic acid cyclohexanol esters were 


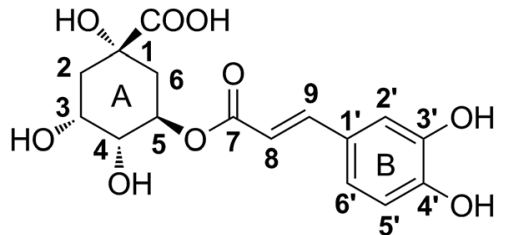

chlorogenic acid, 1<smiles>O=C(O)/C=C/c1ccc(O)c(O)c1</smiles>

caffeic acid, 2<smiles>O=C(O)[C@]1(O)C[C@@H](O)[C@H](O)C[C@@H]1O</smiles>

quinic acid, 3

Fig. 1 The structures of chlorogenic acid, caffeic acid and quinic acid.
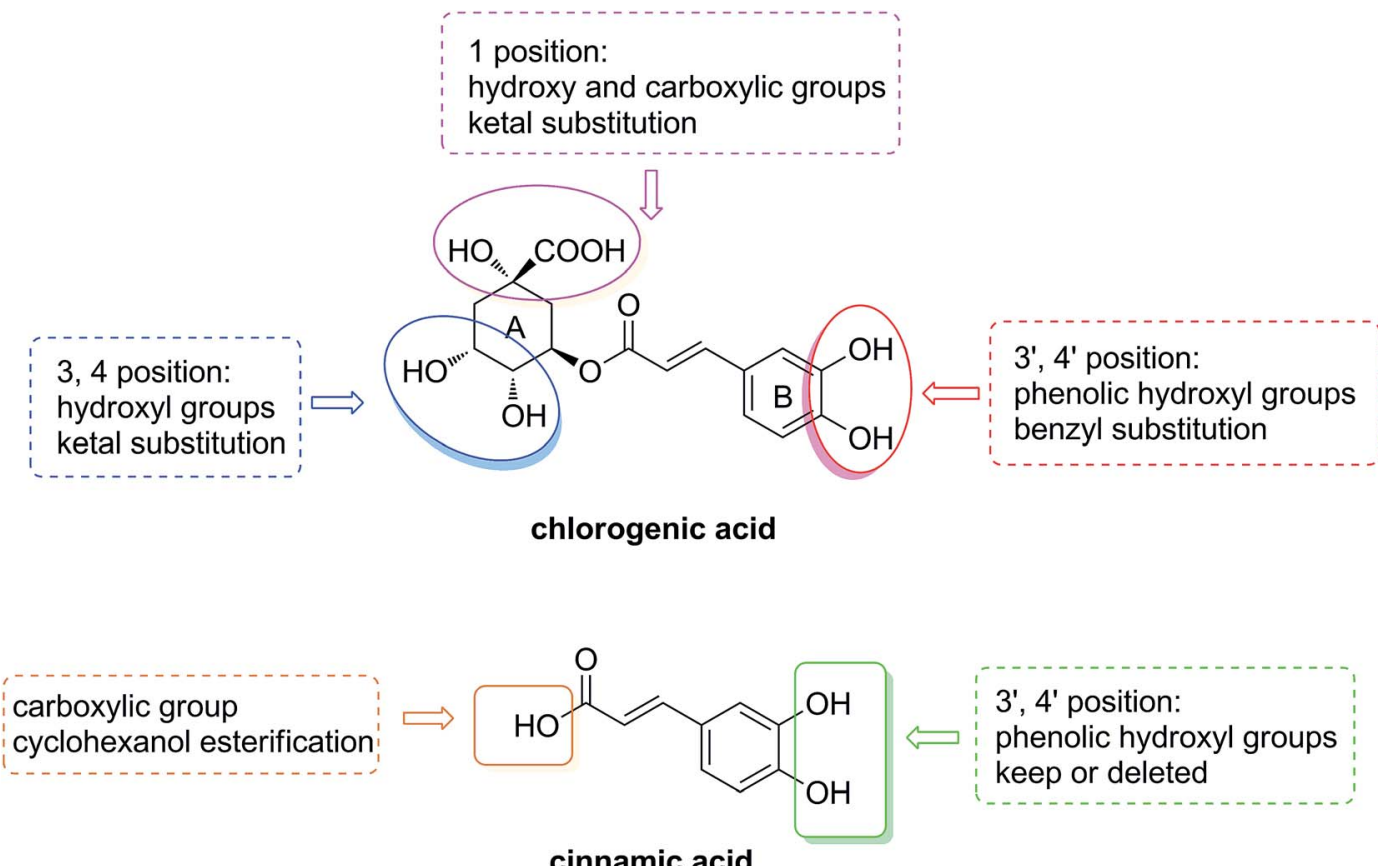

3', 4' position: phenolic hydroxyl groups keep or deleted

cinnamic acid

Fig. 2 The design of structure-activity relationship research.

synthesized to explore the significance of the phenolic hydroxyl groups in chlorogenic acid and caffeic acid. By the approach of a cell-based bioassay ${ }^{26}$ the regulation of above compounds on oleic acid-elicited lipid accumulation in HepG2 cells and the expression of lipogenic, lipid oxidation-related genes are reported in this paper.

\section{Experimental section}

\subsection{General information}

All the reagents were used without further purification unless otherwise specified. Solvents were dried and redistilled prior to use in the usual manner. Analytical TLC was performed using silica gel HF254. Preparative column chromatography was performed with silica gel $\mathrm{H} .{ }^{1} \mathrm{H}$ and ${ }^{13} \mathrm{C}$ NMR spectra were recorded on a Bruker Advance III $600 \mathrm{MHz}$ spectrometer. HRMS were obtained on a Thermofisher LTQ-Obitrap XL.

\subsection{Reagents and materials}

Dulbecco's modified Eagle medium (DMEM), fetal bovine serum were purchased from Corning Inc. (CA, USA). Penicillin and streptomycin were procured from Hyclone (Logan, Utah, USA).
Simvastatin, oil-red O, oleic acid and dimethyl Sulphoxide DMSO were purchased from Sigma-Aldrich (St. Louis, MO, USA). Chlorogenic acid was purchased from the Energy Chemical Company. The kit for Triglyceride (TG) was purchased from Jian Cheng Biotechnology Company (Nanjing, China). Total RNA extraction reagent Trizol was purchased from invitrogen (Carlsbad, CA, USA), PrimeScript RT reagent kit and SYBR-Green PCR kit were purchased from Transgene Biotech, Inc. (Beijing, China).

\subsection{Chemistry}

2.3.1. 3,4-di-O-Isopropylidene-5-O-(3', $\mathbf{4}^{\prime}$-dihydroxycinnamoyl)quinic acid 4. To a solution of chlorogenic acid (1) (3.5 g, $9.9 \mathrm{mmol})$ in dry acetone $(30 \mathrm{~mL})$ and DMP $(20 \mathrm{~mL})$, and catalytic amount of TsOH $(25 \mathrm{mg}$ ) was added. Reaction was monitored by TLC. Then the reaction mixture was stirred at room temperature for $1 \mathrm{~h}$ until its completion, after that $\mathrm{K}_{2} \mathrm{CO}_{3}$ was added to neutralize pH 5-6. The suspension was filtered out and the filtrate was evaporated and purified through column chromatography (eluent: DCM- $\mathrm{CH}_{3} \mathrm{OH}$, $6: 1)$ to offer pure light yellow powder, $90 \%$ yield; ${ }^{1} \mathrm{H}-\mathrm{NMR}(600$ MHz, DMSO- $\left.d_{6}\right) \delta: 9.58\left(1 \mathrm{H}, \mathrm{s}, \mathrm{Ph}^{\prime}-\mathrm{OH}\right), 9.14\left(1 \mathrm{H}, \mathrm{s}, \mathrm{Ph}^{\prime}-\mathrm{OH}\right), 7.48$ $(1 \mathrm{H}, \mathrm{d}, J=15.8 \mathrm{~Hz}, \mathrm{H}-9), 7.05\left(1 \mathrm{H}, \mathrm{d}, J=1.5 \mathrm{~Hz}, \mathrm{H}-2^{\prime}\right), 7.00(1 \mathrm{H}, \mathrm{dd}$, $\left.J=1.4,8.2 \mathrm{~Hz}, \mathrm{H}-6^{\prime}\right), 6.77\left(1 \mathrm{H}, \mathrm{d}, J=8.1 \mathrm{~Hz}, \mathrm{H}-5^{\prime}\right), 6.23(1 \mathrm{H}, \mathrm{d}, J=$ 
$15.9 \mathrm{~Hz}, \mathrm{H}-8), 5.34-5.30$ (1H, m, H-5), 4.39-4.38 (1H, m, H-4), 4.114.09 (1H, m, H-3), 2.20-2.16 (1H, m, H-2, 6), 2.03-2.01 (1H, m, H-2, 6), 1.92-1.89 (1H, m, H-2, 6), 1.83-1.79 (1H, m, H-2, 6), 1.40 (3H, s, $\left.-\mathrm{CH}_{3}\right), 1.25\left(3 \mathrm{H}, \mathrm{s},-\mathrm{CH}_{3}\right) ;{ }^{13} \mathrm{C}-\mathrm{NMR}\left(150 \mathrm{MHz}, \mathrm{DMSO}-d_{6}\right) \delta: 176.2$, 165.8, 148.5, 145.6, 145.4, 125.6, 121.5, 115.8, 114.9, 114.1, 108.1, 76.5, 73.2, 72.7, 70.4, 36.4, 34.8, 28.1, 26.0; HRMS (ESI): calcd for [M $+\mathrm{Na}]^{+} \mathrm{C}_{19} \mathrm{H}_{22} \mathrm{NaO}_{9}$ : 417.1162, found 417.1167.

2.3.2. 3,4-di-O-Isopropylidene-5-( $3^{\prime}, 4^{\prime}$-dihydroxycinnamoyl)1-O-quinic acid isopropylidene ester 5 . To a solution of chlorogenic acid (1) ( $0.35 \mathrm{~g}, 1 \mathrm{mmol})$ in dry tetrahydrofuran (THF) $5 \mathrm{~mL}$, dry acetone $(0.18 \mathrm{~g}, 3 \mathrm{mmol})$ was added. Then lewis acid TMSOTf (165 $\mu \mathrm{L}, 1 \mathrm{mmol}$ ) was dropped at $0{ }^{\circ} \mathrm{C}$ and reacted for overnight. When complete, sodium hydroxide $\left(\mathrm{NaOH}, 1.0 \mathrm{~mol} \mathrm{~L}^{-1}\right) 0.18 \mathrm{~mL}$ was added to quench the reaction. Then the crude product was extracted with ethyl acetate $20 \mathrm{~mL}$, evaporated and subjected to column chromatography (eluent: PE-EtOAc, $10: 1$ ) to gain pure light yellow powder, $65 \%$ yield; ${ }^{1} \mathrm{H}-\mathrm{NMR}\left(600 \mathrm{MHz}, \mathrm{DMSO}-d_{6}\right) \delta$ : $9.60(1 \mathrm{H}, \mathrm{s}, \mathrm{Ph}-\mathrm{OH}), 9.16(1 \mathrm{H}, \mathrm{s}, \mathrm{Ph}-\mathrm{OH}), 7.51(1 \mathrm{H}, \mathrm{d}, J=$ $15.8 \mathrm{~Hz}, \mathrm{H}-9), 7.11-6.95\left(2 \mathrm{H}, \mathrm{m}, \mathrm{H}-2^{\prime}, 6^{\prime}\right), 6.77(1 \mathrm{H}, \mathrm{d}, J=7.7 \mathrm{~Hz}$, $\left.\mathrm{H}-5^{\prime}\right), 6.25$ (1H, d, $\left.J=15.8 \mathrm{~Hz}, \mathrm{H}-8\right), 5.24-5.10$ (1H, m, H-5), 4.504.36 (1H, m, H-4), 4.26-4.14 (1H, m, H-3), 2.29-2.18 (2H, m, H-2, 6), 2.14-2.04 (1H, m, H-2, 6), 1.90-1.79 (1H, m, H-2, 6), 1.57 (6H, s, $\left.2 \times-\mathrm{CH}_{3}\right), 1.41\left(3 \mathrm{H}, \mathrm{s},-\mathrm{CH}_{3}\right), 1.27\left(3 \mathrm{H}, \mathrm{s},-\mathrm{CH}_{3}\right) ;{ }^{13} \mathrm{C}-\mathrm{NMR}(150$ MHz, DMSO- $\left.d_{6}\right) \delta: 173.7,165.9,148.4,145.7,145.6,125.5,121.4$, 115.8, 114.9, 113.7, 110.4, 108.2, 78.2, 75.6, 72.5, 69.4, 35.7, 34.0, 28.1, 27.9, 27.8, 25.7; HRMS (ESI): calcd for $[\mathrm{M}+\mathrm{Na}]^{+}$ $\mathrm{C}_{22} \mathrm{H}_{26} \mathrm{NaO}_{9}$ : 457.1475, found 457.1472.

2.3.3. 3,4-di-O-Isopropylidene-5- $O$ - $\left(3^{\prime}, 4^{\prime}\right.$-dibenzyloxycinn amoyl)-quinic acid benzyl ester 6. A mixture of $4(0.05 \mathrm{~g}, 0.13$ $\mathrm{mmol})$ and $\mathrm{K}_{2} \mathrm{CO}_{3}(0.09 \mathrm{mg}, 0.6 \mathrm{mmol})$ was stirred in dry $\mathrm{CH}_{3} \mathrm{CN} 20 \mathrm{~mL}$, then $5 \mu \mathrm{L} \mathrm{BnBr}$ was dropped, and refluxed under $\mathrm{N}_{2}$ until completion. The mixture was added ethyl acetate $20 \mathrm{ml}$. The combined organic layer was washed with $5 \% \mathrm{NaHCO}_{3}$ aqueous solution, and $\mathrm{NaCl}$ saturated aqueous solution in sequence, and then dried over $\mathrm{Na}_{2} \mathrm{SO}_{4}$ and purified through column chromatography (eluent: PE-EtOAc, $1: 1)$ to offer pure white solid, $67 \%$ yield; ${ }^{1} \mathrm{H}-\mathrm{NMR}(600 \mathrm{MHz}$, DMSO- $\left.d_{6}\right) \delta: 7.55(1 \mathrm{H}, \mathrm{d}, J=15.7 \mathrm{~Hz}, \mathrm{H}-9), 7.50$ (1H, d, $J=$ $\left.1.7 \mathrm{~Hz}, \mathrm{Bn}^{\prime}-\mathrm{H}\right), 7.47-7.44\left(4 \mathrm{H}, \mathrm{m}, \mathrm{Bn}^{\prime}-\mathrm{H}\right), 7.40-7.36(8 \mathrm{H}, \mathrm{m}$, $\left.\mathrm{Bn}^{\prime}-\mathrm{H}\right), 7.33-7.31\left(3 \mathrm{H}, \mathrm{m}, \mathrm{Bn}^{\prime}-\mathrm{H}, \mathrm{H}-2^{\prime}\right), 7.22(1 \mathrm{H}, \mathrm{dd}, J=$ $\left.2.0 \mathrm{~Hz}, 8.3 \mathrm{~Hz}, \mathrm{H}-6^{\prime}\right), 7.08\left(1 \mathrm{H}, \mathrm{d}, J=8.3 \mathrm{~Hz}, \mathrm{H}-5^{\prime}\right), 6.50(1 \mathrm{H}, \mathrm{d}$, $J=15.9 \mathrm{~Hz}, \mathrm{H}-8), 5.37-5.33$ (1H, m, H-5), 5.19 (4H, s, Bn'$\mathrm{CH}_{2}$ ), 5.15-5.09 (2H, m, Bn'- $\mathrm{CH}_{2}$ ), 4.41-4.39 (1H, m, H-4), 4.12-4.11 (1H, m, H-3), 2.24-2.20 (1H, m, H-2, 6), 2.10-2.07 (1H, m, H-2, 6), 1.99-1.96 (1H, m, H-2, 6), 1.88-1.84 (1H, m, $\mathrm{H}-2,6), 1.41\left(3 \mathrm{H}, \mathrm{s},-\mathrm{CH}_{3}\right), 1.26\left(3 \mathrm{H}, \mathrm{s},-\mathrm{CH}_{3}\right) ;{ }^{13} \mathrm{C}-\mathrm{NMR}(150$ MHz, DMSO- $\left.d_{6}\right) \delta: 174.2,166.3,151.2,149.0,145.1,137.0$, 136.8, 135.2, 128.8, 128.7, 128.7, 128.3, 128.1, 128.0, 127.4, 127.3, 123.1, 115.9, 114.3, 113.9, 109.7, 77.4, 77.0, 74.0, 71.4, 71.1, 70.7, 67.9, 37.0, 34.5, 28.1, 26.0; HRMS (ESI): calcd for $[\mathrm{M}+\mathrm{Na}]^{+} \mathrm{C}_{40} \mathrm{H}_{40} \mathrm{NaO}_{9}: 687.2570$, found 687.2573.

2.3.4. General procedure for the synthesis of compounds 11-14. To a solution of cinnamic acid 7-10 (0.55 $\mathrm{mmol})$ in dry 1,4-dioxane $(10 \mathrm{~mL}), \mathrm{SOCl}_{2}(0.37 \mathrm{mmol})$ were added dropwise and stirred under reflux for $2 \mathrm{~h}$. To this mixture, $n$-hexanol (0.37 mmol) was added respectively at $0{ }^{\circ} \mathrm{C}$ and the reaction mixture was stirred until its completion during 4-6 h. The solvent was evaporated and purified through column chromatography to offer pure compounds 11-14.

3,4-Dihydroxycinnamic acid cyclohexanol ester (11). Column chromatography (eluent: $\mathrm{DCM}-\mathrm{CH}_{3} \mathrm{OH}, 10: 1$ ), white power, 68\% yield; ${ }^{1} \mathrm{H}-\mathrm{NMR}\left(600 \mathrm{MHz}, \mathrm{CDCl}_{3}\right) \delta: 7.57(\mathrm{~d}, J=15.9 \mathrm{~Hz}, 1 \mathrm{H}$, $\mathrm{CH}=\mathrm{CH}), 7.11(\mathrm{~d}, J=2.0 \mathrm{~Hz}, 1 \mathrm{H}, \mathrm{H}-2), 7.02(\mathrm{dd}, J=8.2 \mathrm{~Hz}$, $2.0 \mathrm{~Hz}, 1 \mathrm{H}, \mathrm{H}-6), 6.88$ (d, $J=2.0 \mathrm{~Hz}, 1 \mathrm{H}, \mathrm{H}-5), 6.27$ (d, $J=$ $15.9 \mathrm{~Hz}, 1 \mathrm{H}, \mathrm{CH}=\mathrm{CH}), 4.90-4.86(\mathrm{~m}, 1 \mathrm{H}, \mathrm{O}-\mathrm{CH}), 1.93-1.90(\mathrm{~m}$, $\left.2 \mathrm{H}, \mathrm{O}-\mathrm{CH}-\mathrm{CH}_{2}\right), 1.79-1.74\left(\mathrm{~m}, 2 \mathrm{H}, \mathrm{O}-\mathrm{CH}-\mathrm{CH}_{2}\right), 1.58-1.25(\mathrm{~m}$, $\left.6 \mathrm{H},-\left(\mathrm{CH}_{2}\right)_{3}-\right) ;{ }^{13} \mathrm{C}-\mathrm{NMR}\left(150 \mathrm{MHz}, \mathrm{CDCl}_{3}\right) \delta: 167.7,146.5,144.9$, 143.9, 127.6, 122.4, 116.2, 115.6, 114.6, 73.3, 31.8, 25.5, 23.9.

Cinnamic acid cyclohexanol ester (12). Column chromatography (eluent: PE-EA, $30: 1$ ), colourless oil, 53\% yield; ${ }^{1} \mathrm{H}-\mathrm{NMR}$ (600 MHz, pyridine- $d_{5}$ ) $\delta: 7.67(\mathrm{~d}, J=16.1 \mathrm{~Hz}, 1 \mathrm{H}, \mathrm{CH}=\mathrm{CH})$, 7.54-7.52 (m, 2H, H-2, 6), 7.38-7.37 (m, 1H, H-3, 4, 5), 6.44 (d, J $=16.0 \mathrm{~Hz}, 1 \mathrm{H}, \mathrm{CH}=\mathrm{CH}), 4.91-4.87(\mathrm{~m}, 1 \mathrm{H}, \mathrm{O}-\mathrm{CH}), 1.94-1.91$ (m, 2H, O-CH- $\mathrm{CH}_{2}$ ), 1.79-1.75 (m, 2H, O-CH- $\mathrm{CH}_{2}$ ), 1.61-1.25 $\left(\mathrm{m}, 6 \mathrm{H},-\left(\mathrm{CH}_{2}\right)_{3}-\right) ;{ }^{13} \mathrm{C}-\mathrm{NMR}\left(150 \mathrm{MHz}, \mathrm{CDCl}_{3}\right) \delta: 166.5,144.4$, 134.6, 130.2, 129.0, 128.1, 119.0, 72.9, 31.9, 25.5, 23.9.

3-Hydroxycinnamic acid cyclohexanol ester (13). Column chromatography (eluent: PE-EA, $20: 1$ ), white solid, 62\% yield; ${ }^{1} \mathrm{H}-\mathrm{NMR}\left(600 \mathrm{MHz}\right.$, pyridine- $\left.d_{5}\right) \delta: 7.60(\mathrm{~d}, J=16.0 \mathrm{~Hz}, 1 \mathrm{H}, \mathrm{CH}=$ $\mathrm{CH}$ ), 7.22-7.19 (m, 1H, H-5), 7.05-7.02 (m, 1H, H-4, 6), 6.91-6.89 $(\mathrm{m}, 1 \mathrm{H}, \mathrm{H}-2), 6.38(\mathrm{~d}, J=16.0 \mathrm{~Hz}, 1 \mathrm{H}, \mathrm{CH}=\mathrm{CH}), 4.90-4.86(\mathrm{~m}$, 1H, O-CH), 1.92-1.91 (m, 2H, O-CH- $\left.\mathrm{CH}_{2}\right), 1.78-1.72(\mathrm{~m}, 2 \mathrm{H}, \mathrm{O}-$ $\left.\mathrm{CH}-\mathrm{CH}_{2}\right), 1.57-1.23\left(\mathrm{~m}, 6 \mathrm{H},-\left(\mathrm{CH}_{2}\right)_{3}{ }^{-}\right) ;{ }^{13} \mathrm{C}-\mathrm{NMR}(150 \mathrm{MHz}$, $\left.\mathrm{CDCl}_{3}\right) \delta: 167.0,156.9,144.7,135.9,130.0,120.3,118.8,117.7$, $114.7,73.2,31.8,25.5,23.9$.

4-Hydroxycinnamic acid cyclohexanol ester (14). Column chromatography (eluent: PE-EA, $20: 1$ ), white solid, 64\% yield; ${ }^{1} \mathrm{H}-\mathrm{NMR}\left(600 \mathrm{MHz}\right.$, pyridine- $\left.d_{5}\right) \delta: 7.61(\mathrm{~d}, J=15.9 \mathrm{~Hz}, 1 \mathrm{H}, \mathrm{CH}=$ $\mathrm{CH}$ ), 7.38-7.37 (m, 2H, H-2, 6), 6.87-6.86 (m, 2H, H-3, 5), 6.26 (d, $J=15.9 \mathrm{~Hz}, 1 \mathrm{H}, \mathrm{CH}=\mathrm{CH}), 4.89-4.86(\mathrm{~m}, 1 \mathrm{H}, \mathrm{O}-\mathrm{CH}), 1.91-1.90$ $\left(\mathrm{m}, 2 \mathrm{H}, \mathrm{O}-\mathrm{CH}-\mathrm{CH}_{2}\right), 1.79-1.72\left(\mathrm{~m}, 2 \mathrm{H}, \mathrm{O}-\mathrm{CH}-\mathrm{CH}_{2}\right), 1.55-1.22$ $\left(\mathrm{m}, 6 \mathrm{H},-\left(\mathrm{CH}_{2}\right)_{3}-\right) ;{ }^{13} \mathrm{C}-\mathrm{NMR}\left(150 \mathrm{MHz}, \mathrm{CDCl}_{3}\right) \delta: 168.0,158.5$, 145.0, 130.1, 126.8, 116.1, 115.6, 73.3, 31.8, 25.5, 23.9.

\subsection{Evaluation of the biological activity}

2.4.1. Cell culture. HepG2 cells were originated from American Type Culture Collection (ATCC) (Manassas, VA, USA) and obtained from the Peking Union Medical College (Beijing, China). HepG2 cells were cultured in Dulbecco's modified Eagle medium (DMEM) supplemented with 10\% fetal bovine serum, $1 \%$ penicillin and streptomycin at $37^{\circ} \mathrm{C}$ in $5 \% \mathrm{CO}_{2}$ atmosphere. When grown to $70-80 \%$ confluence, cells were incubated in serum-free DMEM containing $100 \mu \mathrm{mol} \mathrm{L}^{-1}$ oleic acid and cotreated with $10 \mu \mathrm{mol} \mathrm{L}{ }^{-1}$ of simvastatin or CA, compound 46, 11-14 for $24 \mathrm{~h}$ respectively. Cells maintained in serum-free DMEM were used as the blank control. Compounds were dissolved in dimethyl sulphoxide (DMSO) and the equal volume of it was added in control group.

2.4.2. Oil red O staining. The cells with $70-80 \%$ confluence in 96 well plates were incubated in serum-free DMEM + OA (100

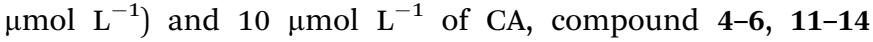
respectively or the positive control simvastatin $\left(10 \mu \mathrm{mol} \mathrm{L}^{-1}\right)$ for $24 \mathrm{~h}$. Cells were then fixed with $4 \% \mathrm{w} / \mathrm{v}$ paraformaldehyde 
(30 min, room temperature) and stained with $0.5 \%$ filtered oilred $\mathrm{O}$ solution (15 $\mathrm{min}$, room temperature). The staining was evaluated by a Tecan Infinite M1000Pro Microplate Reader and spectrophotometry at $358 \mathrm{~nm}$.

2.4.3. Intracellular TG quantification. HepG 2 cells with 70 $80 \%$ confluence in 6 well plates were incubated in serum-free $\mathrm{DMEM}+\mathrm{OA}\left(100 \mu \mathrm{mol} \mathrm{L} \mathrm{L}^{-1}\right)$ and $10 \mu \mathrm{mol} \mathrm{L}^{-1}$ of CA, compound 4-6, 11-14 respectively or the positive control simvastatin $\left(10 \mu \mathrm{mol} \mathrm{L}^{-1}\right)$ for $24 \mathrm{~h}$. The cells were subjected to TG quantification as introduced by the protocol of Triglyceride Quantification Kit. Each experiment was repeated in triplicate with duplicates each.

2.4.4. Real-time quantitative PCR. Cells were treated with OA $\left(100 \mu \mathrm{mol} \mathrm{L}^{-1}\right)$ and $10 \mu \mathrm{mol} \mathrm{L}{ }^{-1}$ of CA or compound 4-6, 1114 for $24 \mathrm{~h}$ respectively. Total RNA was extracted with Trizol reagent and was reversely transcribed to CDNA with the PrimeScript RT reagent Kit. Quantitative RT-PCR was performed using SYBR-Green PCR kit. At least three independent biological replicates were performed to verify the reproducibility of the data. The gene-specific primers used for quantitative PCR are listed in Table 1. Data are presented as fold change in the experimental group normalized to $\beta$-actin and relative to the control group.

2.4.5. Statistical analysis. Data are expressed as mean \pm SEM. One-way ANOVA was used to determine significant differences among groups, after which the modified Students $t$ test with the Bonferroni correction was used for comparison between individual groups. All statistical analyses were performed with SPSS 17.0 software (SPSS Inc., Chicago, IL, USA). $P$ $<0.05$ was considered statistically significant.

\section{Results and discussion}

\subsection{Chemistry}

The synthesis of analogues 4-6 is outlined in Fig. 3. The naturally abundant chlorogenic acid (1) was treated with 2,2-dimethoxypropane (DMP) and $p$-toluenesulfonic acid (TsOH) in dry acetone to obtain compound 4. Moreover, compound 1 reacted with dry acetone in Lewis acidic conditions trimethylsilyl trifluoromethanesulfonate (TMSOTf) to provided compound $\mathbf{5}$. Compound 6 was attained via alkylation of compound 4 with benzyl bromide $(\mathrm{BnBr})$ and potassium carbonate $\left(\mathrm{K}_{2} \mathrm{CO}_{3}\right)$ in acetonitrile.

The synthesis of cinnamic acid ester analogues 11-14 is showed in Fig. 4. Compounds 7-10 were reacted respectively with cyclohexanol in the presence of sulfoxide chloride $\left(\mathrm{SOCl}_{2}\right)$, and finally gained the target compounds 11-14.

\subsection{Biological assessment}

3.2.1. The regulation of compound 4-6 on OA-elicited lipid accumulation in HepG2 cells. Liver is the most metabolically active organ that regulates lipid metabolic homeostasis. ${ }^{27}$ Nonalcoholic fatty liver disease (NAFLD) resulted from lipid metabolism abnormalities is characterized with the excessive amount of triglyceride and other fats in hepatocytes, ${ }^{28}$ which is closely associated with the development of CVD and nonalcoholic steatohepatitis (NASH) related hepatocellular carcinogenesis. ${ }^{\mathbf{2 9}, 30}$ Here, oleic acid induced lipid accumulation in HepG2 cells was used as a cell model. ${ }^{31}$ Caffeic acid and quinic acid are two structure components of CA. To investigate their contribution for lipid-lowering activity of CA, we synthesized 3 CA analogues with 3,4-position hydroxyl groups modified designated 4, 1,3,4-position hydroxyl and 1-carboxyl modified designated $\mathbf{5}$ as well as compound $\mathbf{6}$ obtained by further alkylation of $3^{\prime}, 4^{\prime}$-phenolic hydroxyl and 1-carboxyl in compound 4 respectively, and evaluated their lipid-lowering effect through oil red $\mathrm{O}$ staining and intracellular TG assay. The result showed oleic acid dramatically stimulated lipid accumulation with alleviated triglyceride concentration in HepG2 cells. The supplementation of $10 \mu \mathrm{M}$ compound 4, 5 significantly decreased lipid accumulation and intracellular triglyceride levels whereas $10 \mu \mathrm{M}$ compound 6 exhibited no efficacy (Fig. 5A and B). Additionally, compound 4, 5 and CA at $10 \mu \mathrm{M}$ showed similar in potency (CA: 4: 5; OD: 2.63, 2.62, 2.63; TG: 38.6, 38.6,

Table 1 The primers used in real-time quantitative PCR analysis

\begin{tabular}{lll}
\hline Name & Forward $\left(5^{\prime}-3^{\prime}\right)$ & Reverse $\left(5^{\prime}-3^{\prime}\right)$ \\
\hline SREBP1c & CCATGGATGCACTTTCGAA & CCAGCATAGGGTGGGTCAA \\
ACC & TGATGTCAATCTCCCCGCAGC & TTGCTTCTTCTCTGTTTCTCCCC \\
FAS & CGGTACGCGACGGCTGCCTG & GCTGCTCCACGAACTCAAACACCG \\
SREBP1a & TGCTGACCGACATCGAAGAC & CCAGCATAGGGTGGGTCAA \\
PPAR $\alpha$ & AAAAGCCTAAGGAAACCGTTCTG & TATCGTCCGGGTGGTTGCT \\
-Actin & CCTGGCACCCCAGCACAAT & GCCGATCCACACACGGAGTACT
\end{tabular}
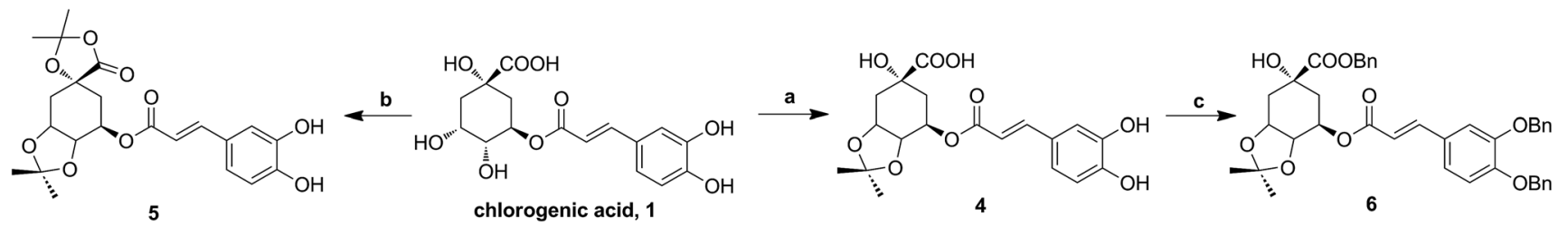

Fig. 3 The synthesis of chlorogenic acid analogues. Reagents and conditions: (a) DMP, TsOH; (b) TMSOTf, acetone; (c) BnBr, $\mathrm{K}_{2} \mathrm{CO}_{3}$. 
<smiles>[R]c1ccc(/C=C/C(=O)O)cc1[R]</smiles>

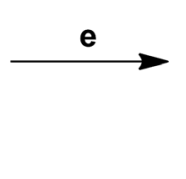<smiles>[R2]c1ccc(/C=C/C(=O)OC2CCCCC2)cc1[R]</smiles>
7, $11 \mathrm{R}_{1}=\mathrm{OH}, \mathrm{R}_{2}=\mathrm{OH}$
8, $12 \mathrm{R}_{1}=\mathrm{H}, \mathrm{R}_{2}=\mathrm{H}$
9, $13 \mathrm{R}_{1}=\mathrm{OH}, \mathrm{R}_{2}=\mathrm{H}$
10, $14 \mathrm{R}_{1}=\mathrm{H}, \mathrm{R}_{2}=\mathrm{OH}$

Fig. 4 The synthesis of a series of cinnamic acid ester derivatives. Reagents and conditions: (e) $\mathrm{SOCl}_{2}$, $\mathrm{Cyclohexanol}$ reflux.

39.2). This hypolipidemic effect of $\mathbf{4}, \mathbf{5}$ displayed by oil red $\mathrm{O}$ staining (Fig. 5C and D) was dose-dependent (1-10 $\mu \mathrm{M})$. These results suggested that the reservation of caffeic acid moiety retained lipid-lowering effect while the functional groups of quinic acid moiety had little influence on the function.

3.2.2. The regulation of compound 11-14 on OA-elicited lipid accumulation in HepG2 cells. To further investigate the role of caffeic acid moiety in CA alleviating lipid accumulation, we synthesized a series of cinnamic acid cyclohexanol ester analogues 11-14 (Fig. 4). Compounds 11, 13, 14, possessing 3,4-phenolic hydroxyl, 3-phenolic hydroxyl and 4-phenolic hydroxyl respectively, were assessed for inhibition effect against OA-induced lipid accumulation in HepG2 cells. Oil red $\mathrm{O}$ staining and intracellular TG levels showed (Fig. 6A and B) 10 $\mu \mathrm{M}$ of analogues 11, 13, 14 exhibited higher efficacy than that of parental compound CA on attenuating lipid accumulation. The potency of compounds $11, \mathbf{1 3}, \mathbf{1 4}$ were approximately close at 10 $\mu \mathrm{M}$. Moreover, this lipid-lowering activity showed in a dosedependent way from 1 to $10 \mu \mathrm{M}$ (Fig. 6C-E). Compound 12 (10 $\mu \mathrm{M})$ characterized with 3,4-phenolic hydroxyl replaced exhibited no lipid-lowering effect. These data indicate that phenolic hydroxyl in caffeic acid moiety is responsible for

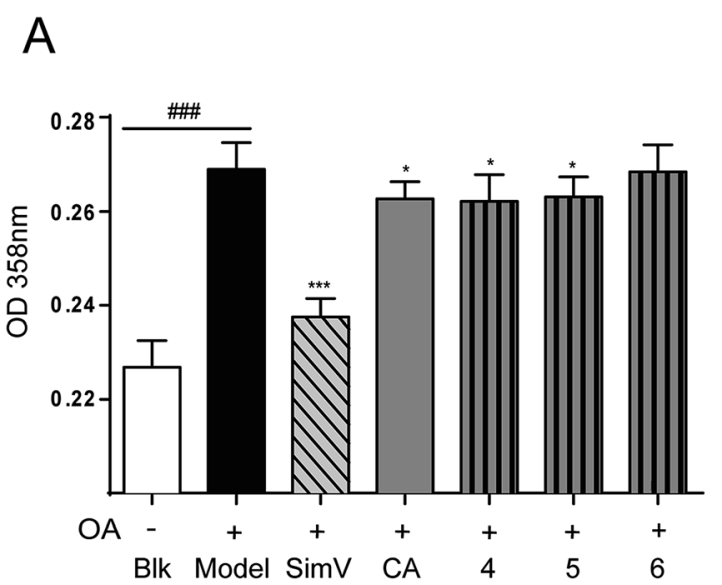

B

C
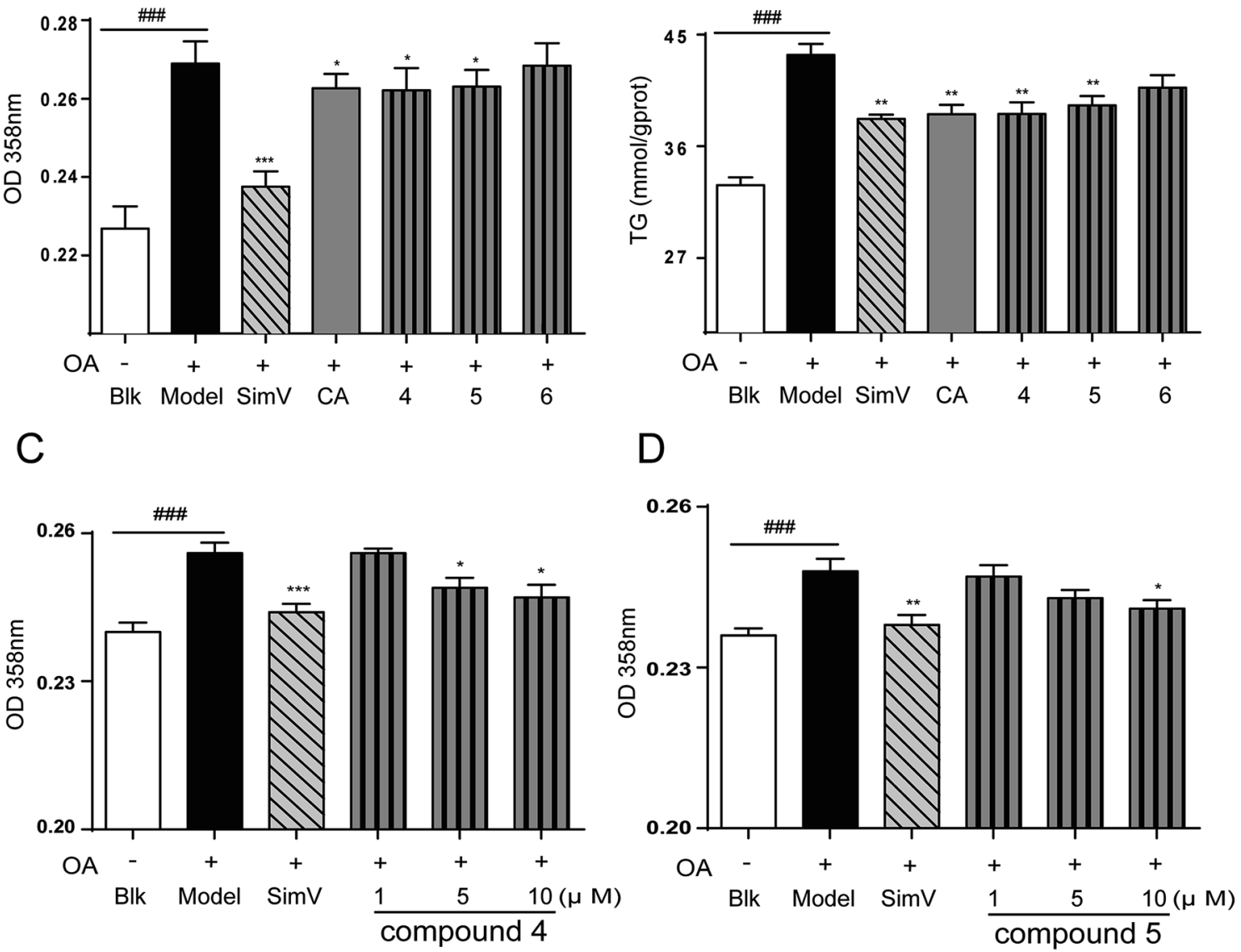

Fig. 5 Effects of CA analogues 4-6 (10 $\left.\mu \mathrm{mol} \mathrm{L}^{-1}\right)$ on OA-elicited lipid accumulation in HepG2 cells. (A) $358 \mathrm{~nm}$ measurement after oil-red O staining $(n=8)$; (B) intracellular TG levels $(n=6)$; (C) and (D) compounds 4, 5 inhibited OA-elicited lipid accumulation in a dose-dependent way. Data are depicted as means \pm SEM. ${ }^{\# \# \# ~} p<0.001$, model vs. blank; ${ }^{*} p<0.05,{ }^{* *} p<0.01$, test groups vs. model group. Blk: blank; SimV: simvastatin, used as a positive control; CA: chlorogenic acid; compound 4: 3,4-di-O-isopropylidene-5-O-( $3^{\prime}, 4^{\prime}$-dihydroxycinnamoyl)-quinic acid; compound 5: 3,4-di-O-isopropylidene-5-(3',4'-dihydroxycinnamoyl)-1-O-quinic acid isopropylidene ester; compound 6: 3,4-di-O-isopropylidene-5-O- $\left(3^{\prime}, 4^{\prime}\right.$-dibenzyloxycinnamoyl)-quinic acid benzyl ester. 
hypolipidemic effect rather than quinic moiety, the amount and the position of phenolic hydroxyl groups have no considerable effect on the activity. We also assessed the effect of caffeic acid on decreasing lipid content (Fig. 6D), It showed that caffeic acid displayed the similar efficacy with that of analogue 13 of better potency at $10 \mu \mathrm{M}$, which supports the important role of caffeic acid moiety in lipid-lowering CA.

3.2.3. The primary SARs of chlorogenic acid and caffeic acid on lipid-lowering effects. The study of structure and activity of chlorogenic acids is of high significance in developing novel drugs for their multiple biological properties. For example, replacement of quinic by glucuronic moiety yields chlorogenic acid mimics with high antioxidant activity. ${ }^{32}$ In this study, the preliminary SARs guided by cell-based bioassay suggest that, in general, caffeic acid moiety is essential for lipid-lowering effect of CA rather than quinic acid moiety. The isopropylidene substituent of 3,4-position hydroxyl groups and 1-position hydroxyl and carboxyl group on quinic acid moiety in A ring (compounds 4 and 5) had little effect on the activity, indicating that the hydroxyl groups and carboxyl group on quinic acid moiety are not required for activity. While the introduction of benzyl groups substituent on the phenolic hydroxyl groups in caffeic acid moiety of B ring (compounds 6) largely deteriorated this regulation on attenuating lipid accumulation, which elucidates the phenolic hydroxyl groups on chlorogenic acid are potential and vital for lipid-lowering function. Furthermore, caffeic acid cyclohexanol ester (compounds 11) increased lipidlowering activity compared to the parent compound CA, whereas cinnamic acid cyclohexanol ester (compounds 12) with no phenolic hydroxyl group substituted showed an inactive effect. This result proved again that the replacement of the quinic acid moiety to cyclohexanol would have little influence the lipid-lowering activity. Though there are few studies that investigate structure-hypolipidemic activity of CA, numerous papers have revealed that caffeic acid attenuates lipid accumulation in vivo and in vitro ${ }^{33,34}$ which in some aspects supported our findings. These results provide an evidence for developing CA-derived new chemical agents that improve lipid accumulation.

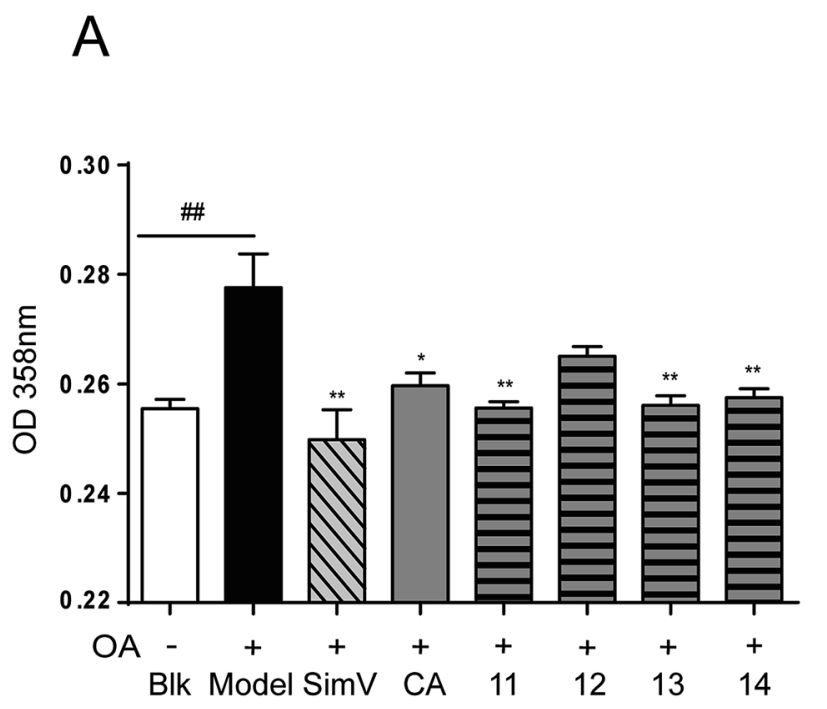

B
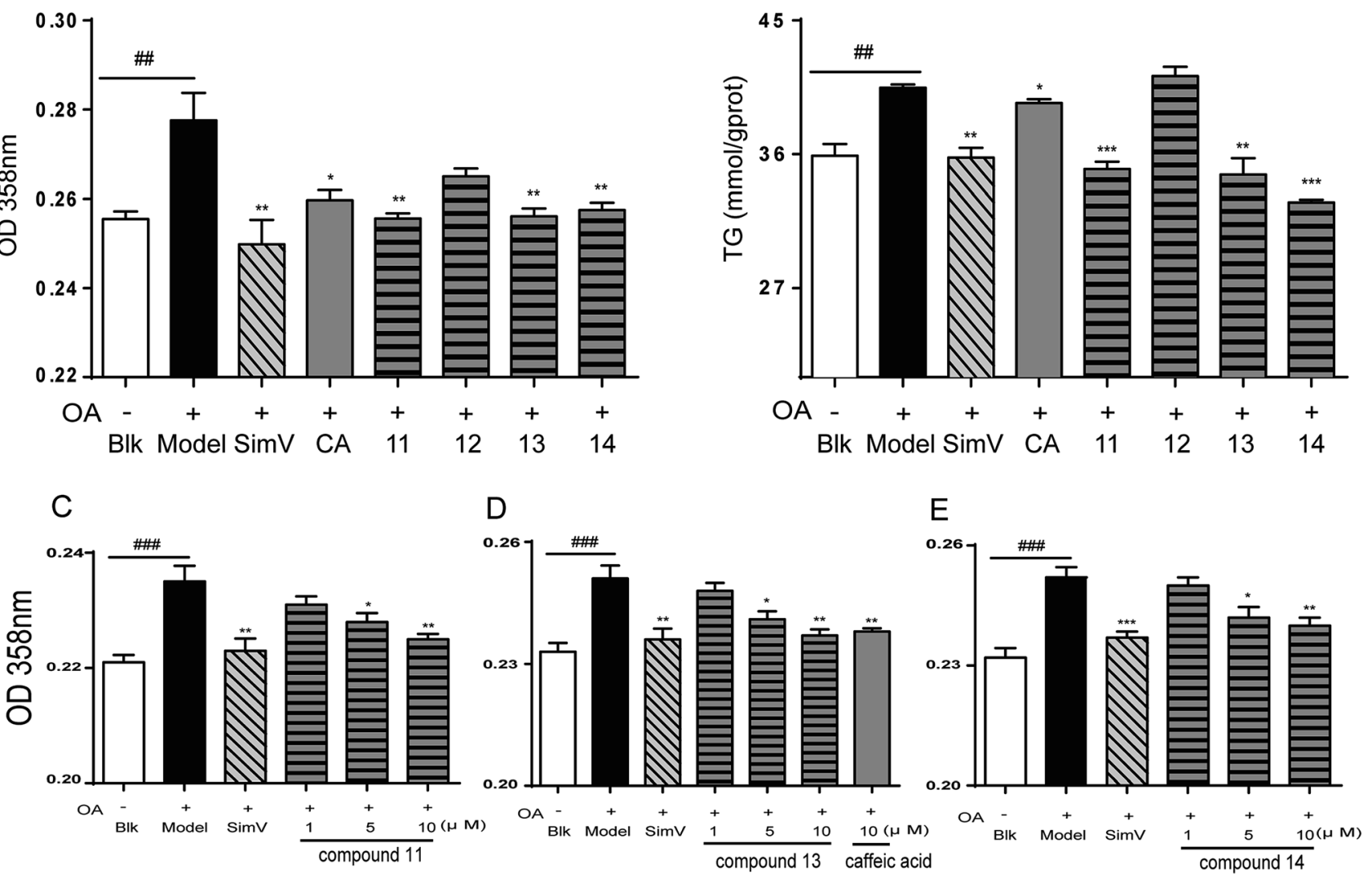

Fig. 6 Effects of CA analogues 11-14 (10 $\left.\mu \mathrm{mol} \mathrm{L}^{-1}\right)$ on OA-elicited lipid accumulation in HepG2 cells. (A) $358 \mathrm{~nm}$ measurement after oil-red O staining $(n=8)$; (B) intracellular TG levels $(n=6)$; (C-E) compounds 11, 13, 14 inhibited OA-elicited lipid accumulation in a dose-dependent way. Data are depicted as means \pm SEM. ${ }^{\# \#} p<0.01$, model vs. blank; ${ }^{*} p<0.05,{ }^{* *} p<0.01,{ }^{* * *} p<0.001$, test groups vs. model group. Blk: blank; SimV: simvastatin, used as a positive control; CA: chlorogenic acid; compound 11: 3,4-dihydroxycinnamic acid cyclohexanol ester; compound 12: cinnamic acid cyclohexanol ester; compound 13: 3-hydroxycinnamic acid cyclohexanol ester; compound 14: 4-hydroxycinnamic acid cyclohexanol ester. 

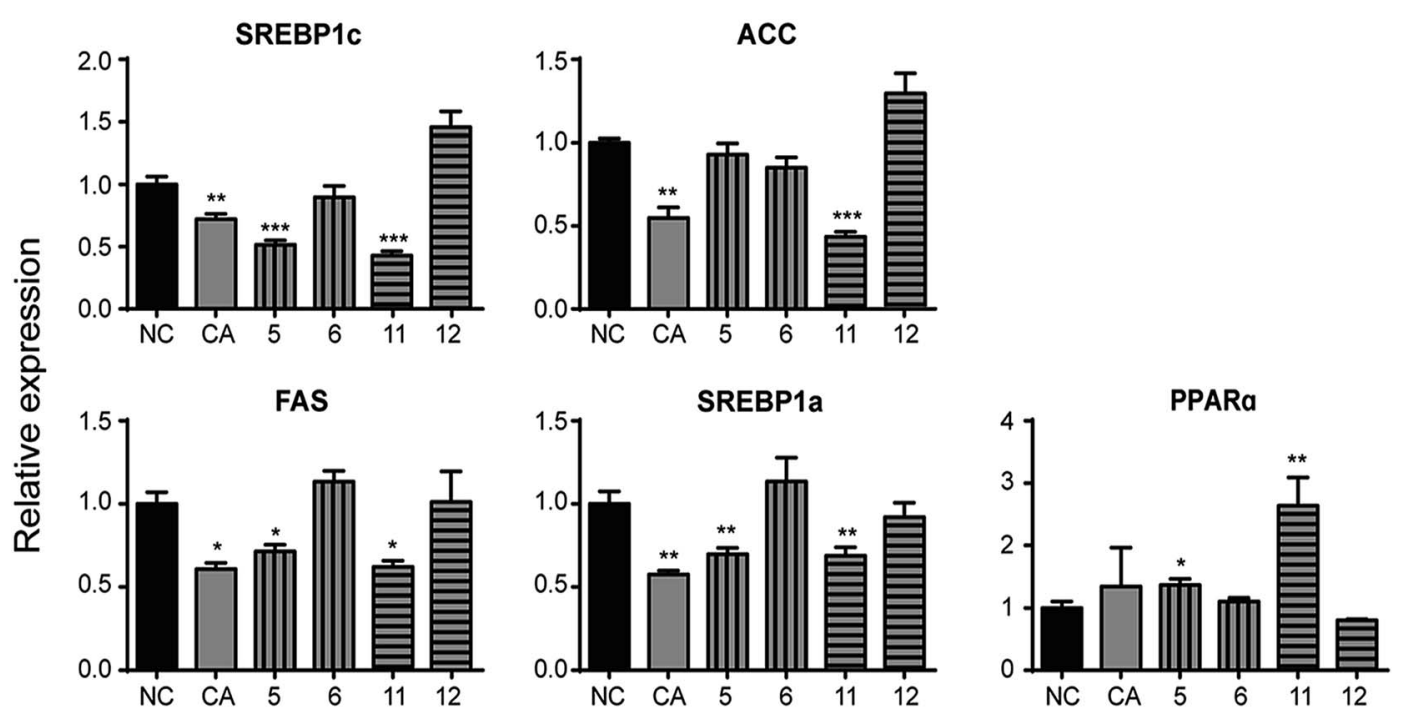

Fig. 7 Effects of $C A$ and its analogues $\left(10 \mu \mathrm{mol} \mathrm{L} \mathrm{L}^{-1}\right)$ on the mRNA levels of lipogenic genes SREBP1c, ACC, FAS, SREBP1a and lipid-oxidation related gene PPAR $\alpha$ in OA-elicited HepG2 cells. Real-time quantitative PCR was conducted with gene-specific oligonucleotide primers. The amplification of $\beta$-actin served as an internal control $(n=6)$. Data are depicted as means \pm SEM. $* p<0.05, * * p<0.01, * * * p<0.001$, test groups vs. negative control group. NC: negative control; CA: chlorogenic acid; compound 5: 3,4-di-O-isopropylidene-5-( $3^{\prime}, 4^{\prime}$-dihydroxycinnamoyl)-1O-quinic acid isopropylidene ester; compound 6: 3,4-di-O-isopropylidene-5-O-( $3^{\prime}, 4^{\prime}$-dibenzyloxycinnamoyl)-quinic acid benzyl ester. compound 11: 3,4-dihydroxycinnamic acid cyclohexanol ester; compound 12: cinnamic acid cyclohexanol ester; SREBP1c/1a: sterol response element binding protein 1c/1a; ACC: acetyl-CoA carboxylase; FAS: fatty acid synthase; PPAR $\alpha$ : peroxisome proliferator-activated receptor $\alpha$.

3.2.4. Caffeic acid moiety affects the regulation of CA on lipometabolic-modulating genes. Lipogenisis and lipid oxidation are considered to be two vital processes to modulate lipid metabolism in liver. SREBP1c is one of the most important transcription factors modulating de novo lipogenesis in the liver and primarily regulates genes involved in fatty acid biosynthesis, including acetyl-CoA carboxylase (ACC) and fatty acid synthase (FAS). ${ }^{35,36}$ Disruption of SREBP1-mediated signal pathway ameliorates fatty liver and suppresses over expression of hepatic FAS. Suppression of liver FAS, ACC attenuates hepatic steatosis, hypertriglyceridemia. ${ }^{37}$ PPAR $\alpha$ is one of fatty acidregulated nuclear hormone receptors that control lipid oxidation and expression of fatty acid transport proteins (FATPs). ${ }^{38,39}$ It is known to be the receptor for fibrates in the therapy of hypertriglyceridemia. The activation of PPAR $\alpha$ promotes lipid metabolism via peroxisomal and mitochondrial $\beta$-oxidation pathways, fatty acid uptake from circulation to cells and triglyceride catabolism. ${ }^{40}$ To investigate the regulation of CA and its analogues on lipometabolic-modulating genes, more specifically, to further illustrate how caffeic acid moiety affects lipid-lowering CA, compound 5, 6, 11, 12 with caffeic acid reserved or modified were selected from 3,4-di-O-isopropylidene-5-O-(dihydroxycinnamoyl)-quinic acid derivatives and cinnamic acid cyclohexanol ester derivatives, and their regulation on these lipometabolic involved genes were assessed (Fig. 7). Real-time quantitative PCR showed the regulation of CA on these genes is in accordance with previous reports. ${ }^{\mathbf{4 1 4 2}}$ The supplementation of compound $\mathbf{1 1}$ with caffeic acid moiety reserved significantly reduced the expression of lipogenic genes SREBP1a/1c as well as its down steam genes ACC, FAS while upregulated the expression of $\operatorname{PPAR} \alpha$. In addition, the modulating effect of compound $\mathbf{1 1}$ was more potential than that of CA. Compound 5, possessing 3,4-phenolic hydroxyl groups, remarkably stimulated down-regulation of SREBP1c/1a, FAS transcription while increased the expression of PPAR $\alpha$. Compound 12 and 6 with no the 3,4-phenolic hydroxyl groups were inactive towards these genes. These results proved our previous data obtained from oil-red O staining and TG levels. Demonstrated that caffeic acid moiety plays an essential role in the regulation of CA on these lipogenic and lipid oxidationrelated genes.

\section{Conclusions}

The study of SAR demonstrated caffeic acid moiety with phenolic hydroxyl is essential for hypolipidemic activity instead of quinic acid moiety. Additionally, the amount and the position of phenolic hydroxyl groups have little influence on lipidlowering CA. Caffeic acid moiety with phenolic hydroxyl directly affects the modulation of CA on altering mRNA levels of lipometabolic-modulating genes. This study introduced a series of chemical agents with improving hypolipdemic activity in vitro, thus are worthy for further study and the report lied foundation for developing novel drugs of promising antihyperlipidemic effect.

\section{Conflicts of interest}

We declare there are no financial or other contractual agreements that might cause conflicts of interest or be perceived as causing conflicts of interest. 


\section{Acknowledgements}

This work was supported by the National Natural Sciences Foundation of China (Grant No. 81302656), Beijing Natural Sciences Foundation (Grant No. 7192129), the CAMS Innovation Fund for Medical Science (CIFMS) (Grant No. 2016-I2M-1-012, 2016-I2M-3-015).

\section{References}

1 E. J. Lee, H. Oh, B. G. Kang, M. K. Kang, D. Y. Kim, Y. H. Kim, J. Y. Lee, J. G. Ji, S. S. Lim and Y. H. Kang, J. Agric. Food Chem., 2018, 66, 10447-10457.

2 K. K. Poh, B. Ambegaonkar, C. A. Baxter, P. Brudi, W. Buddhari, F. T. Chiang, M. Horack, Y. Jang, B. Johnson, D. Lautsch, J. Sawhney, A. Vyas, B. P. Yan and A. K. Gitt, Eur. J. Prev. Cardiol., 2018, 25(18), 1950-1963.

3 C. Wu, Y. Guo, Y. Su, X. Zhang, H. Luan, X. Zhang, H. Zhu, H. He, X. Wang, G. Sun, X. Sun, P. Guo and P. Zhu, J. Cell. Mol. Med., 2014, 18, 293-304.

4 S. Karr, Am. J. Manag. Care, 2017, 23, S139-S148.

5 M. Apostolopoulou, A. Corsini and M. Roden, Eur. J. Clin. Invest., 2015, 45, 745-754.

6 N. Sattar, D. Preiss, H. M. Murray, P. Welsh, B. M. Buckley, A. J. d. Craen, J. J. McMurray, D. J. Freeman and J. W. Jukema, Lancet, 2010, 375, 735-742.

7 J. Chen, W. Li, H. Yao and J. Xu, Fitoterapia, 2015, 103, 231241.

8 H. Yao, J. Liu, S. Xu, Z. Zhu and J. Xu, Expert Opin. Drug Discovery, 2017, 12, 121-140.

9 M. Lahlou, Pharmacology \& Pharmacy, 2013, vol. 04, no. 03, p. 15.

10 L. Zhang, J. Liu, P. Zhang, S. Yan, X. He and F. Chen, Chromatographia, 2011, 73, 129-133.

11 D. D. Rio, A. Stalmach, L. Calani and A. Crozier, Nutrients, 2010, 2, 820-833.

12 A. Karunanidhi, R. Thomas, B. A. Van and V. Neela, BioMed Res. Int., 2013, 2013, 392058.

13 N. Liang and D. D. Kitts, Nutrients, 2016, 8, 16.

14 W. Li, X. Liu, G. Zhang and L. Zhang, Zhongguo Feiai Zazhi, 2017, 20, 555-561.

15 H. Y. Ye, J. Jin, L. W. Jin, Y. Chen, Z. H. Zhou and Z. Y. Li, Inflammation, 2017, 40, 523-529.

16 S. Meng, J. Cao, Q. Feng, J. Peng and Y. Hu, Evid.-Based Complementary Altern. Med., 2013, 2013(4), 801457.

17 K. W. Ong, A. Hsu and B. K. Tan, Biochem. Pharmacol., 2013, 85, 1341-1351.

18 A. S. Cho, S. M. Jeon, M. J. Kim, J. Yeo, K. I. Seo, M. S. Choi and M. K. Lee, Food Cosmet. Toxicol., 2010, 48, 937-943.

19 L. T. Zhang, C. Q. Chang, Y. Liu and Z. M. Chen, Acta Acad. Med. Sin., 2011, 33, 281.

20 C. Wu, X. Zhang, X. Zhang, H. Luan, G. Sun, X. Sun, X. Wang, P. Guo and X. Xu, J. Nutr. Biochem., 2014, 25, 412-419.

21 X. Zhang, C. Wu, H. Wu, L. Sheng, Y. Su, X. Zhang, H. Luan, G. Sun, X. Sun and Y. Tian, PLoS One, 2013, 8, e61922.
22 C. Wu, H. Luan, X. Zhang, S. Wang, X. Zhang, X. Sun and P. Guo, PLoS One, 2014, 9, e95452.

23 C. M. Wu, H. Luan, S. Wang, X. P. Zhang, H. T. Liu and P. Guo, Acta Pharm. Sin., 2015, 50, 278.

24 K. M. Jackson, T. Rathinasabapathy, D. Esposito and S. Komarnytsky, Mol. Nutr. Food Res., 2017, 61(9), 1601118.

25 M. Zhang, W. X. Liu, M. F. Zheng, Q. L. Xu, F. H. Wan, J. Wang, T. Lei, Z. Y. Zhou and J. W. Tan, Molecules, 2013, 18, 14096-14104.

26 S. Wang, C. Wu, X. Li, Y. Zhou, Q. Zhang, F. Ma, J. Wei, X. Zhang and P. Guo, Acta Pharm. Sin. B, 2017, 7, 453-460.

27 S. Chan, R. Q. Sun and X. Y. Zeng, Diabetes, 2013, 62, 20952105.

28 G. Musso, R. Gambino and M. Cassader, Obes. Rev., 2010, 11, 430-445.

29 Y. L. Liu, G. L. Patman, J. B. Leathart, A. C. Piguet, A. D. Burt, J. F. Dufour, C. P. Day, A. K. Daly, H. L. Reeves and Q. M. Anstee, J. Hepatol., 2014, 61, 75-81.

30 T. Utsunomiya and M. Shimada, Hepatol. Res., 2011, 41, 711721.

31 W. Cui, S. L. Chen and K. Q. Hu, Am. J. Transl. Res., 2010, 2, 95-104.

32 M. Szewczyk, M. Morawiak, A. Narczyk, Z. Pakulski and Z. Urbanczyk-Lipkowska, Journal of Chemistry and Biochemistry, 2018, 6, 28-37.

33 M. B. Dantas, T. L. Sampaio, R. Roacute, J. Magalhatilde, E. Ferreira, T. S. Melo, H. G. Rodrigues and D. B. Lima, Afr. J. Pharm. Pharmacol., 2018, 12(20), 263-268.

34 K. Karthikesan and L. Pari, Fundam. Clin. Pharmacol., 2010, 22, 523-527.

35 J. H. Kim, S. I. Kang, H. S. Shin, S. A. Yoon, S. W. Kang, H. C. Ko and S. J. Kim, Journal of the Agricultural Chemical Society of Japan, 2013, 77, 1595-1598.

36 T. Uemura, T. Goto, M. S. Kang, N. Mizoguchi, S. Hirai, J. Y. Lee, Y. Nakano, J. Shono, S. Hoshino, K. Taketani, N. Tsuge, T. Narukami, M. Makishima, N. Takahashi and T. Kawada, J. Nutr., 2011, 141, 17-23.

37 L. P. Bechmann, R. A. Hannivoort, G. Guido, G. K. S. Hotamisligil, T. Michael and C. Ali, J. Hepatol., 2012, 56, 952-964.

38 Q. Liu, B. Yuan, K. A. Lo, H. C. Patterson, Y. Sun and H. F. Lodish, Proc. Natl. Acad. Sci. U. S. A., 2012, 109, 14568-14573.

39 B. Kim, M. J. Woo, C. S. Park, S. H. Lee, J. S. Kim, B. Kim, S. An and S. H. Kim, Phytother. Res., 2017, 31, 132-139.

40 C. Wang, R. Batey, J. Yamahara and Y. Li, J. Funct. Foods, 2017, 36, 43-51.

41 C. W. Wan, C. N. Wong, W. K. Pin, M. H. Wong, C. Y. Kwok, R. Y. Chan, P. H. Yu and S. W. Chan, Phytother. Res., 2013, 27, 545-551.

42 T. Murase, K. Misawa, Y. Minegishi, M. Aoki, H. Ominami, Y. Suzuki, Y. Shibuya and T. Hase, Am. J. Physiol.: Endocrinol. Metab., 2011, 300, 122-133. 